\title{
Quality of Work Life of Employees in I.E.C, Mandideep: An Overview
}

\author{
Dr. P. K. Jain ${ }^{1}$, Shweta Maheshwari ${ }^{2}$ \\ ${ }^{1}$ Professor, ${ }^{2}$ Research Scholar \\ Government Hamidia Arts \& Commerce College, Bhopal, Madhya Pradesh, India
}

\section{ABSTRACT}

The study focuses on overall Quality of Working Life of Employees in Insulators \& Electricals Company, Mandideep. Quality of Working Life of employees in organization cover all dimensions related to workplace that not only include favourable dimensions such as job satisfaction, development of employees skills, performance, efficiency, pay scale, health, safety and physical work environment but also other issues such as occupational stress, burnout that are unfavourable for employees in any organization. The key elements of Quality of Working Life constructs are - Pay Scale, Health Care benefits, Retirement benefits, Job Security, Work Space, special Recognition \& Rewards for achievements, availability of on campus child care, adequate input in management decision making, fair and equitable Performance Appraisal along with equitable distribution of resources that in turn would also lead to Profit \& Wealth Maximization of any organization.

\section{INTRODUCTION}

Work plays an important role in every human being's life. Employees work life helps in shaping their personality, determining performance and so that is why Quality of Working Life is essential in every organization. Employees welfare include monitoring of work environment from time to time, maintaining industrial harmony and peace through infrastructure of health, industrial relations, insurance against disease, accident and employment for employees and their families. Quality of Working Life of employees in organization is a way of thinking about people, work and organization which creates a sense of accomplishment and achievement in mind of employees that contributes to greater job satisfaction, improved productivity, efficiency, performance, skills, adaptability and overall effectiveness in an organization.
The term 'Quality of Working Life' of employees in organization gained importance in late 1960s as a strategy of concern about effects of job or work life on health and general well-being of individual's and various ways to positively upgrade quality of an individual's work and life experiences. Up until the mid 1970s, employer's concern regarding 'Quality of Working Life' of employees was only on work culture and how to enhance working conditions in an organization. But in 1980s, the concept of 'Quality of Working Life' of employees in organization included other aspects that affect Employees Job Satisfaction \& Productivity. These aspects are Pay Scale, Monetary \& C Non-Monetary Benefits, Physical Work Environment \& Work Culture, Employee Involvement in Management Decision Making, Rights \& Esteem Needs of Employees in an organization.

Thus, Quality of Working Life of employees in organization is the sum total of physical (working conditions), psychological, social and economic factors that affect job and employees productivity. Indicators of Quality of Working Life of employees in organization are Job Satisfaction, Job Involvement, Work Role Ambiguity, Work Role Conflict, Work Role Overload, Job Stress, Organizational Commitment \& Turn Over Intentions. According to Amuno - "Quality of Working Life includes Increased Productivity, Improved Quality of Work Life, Polished Skills, Knowledge, Understanding \& Attitude, Enhanced Use of Tools \& Machines, Reduced Wastes, Accidents, Turnover, Lateness, Absenteeism \& Other Overhead Costs, Elimination of Obsolesce in Skills, Technologies, Methods, Products, and Capital Management etc". 
ORGANIZATION PROFILE - INSULATORS \& ELECTRICALS COMPANY (I.E.C)

Insulators \& Electricals Company is country's one of the leading insulator manufacturing plant of Hindustan Vidyut Products Limited a R. P. MODY group was established at Mandideep Industrial Area near by Bhopal state capital of Madhya Pradesh in 1986 with 6000 M.T. per annum installed capacity and by adding 4 more shuttle kiln $\&$ have turnover of around USD 100 Millions (Rs. 500 Crores). This plant was set up in technical collaboration with $\mathrm{M} / \mathrm{s}$. Rheinisch Westfalishe Isolatoran - Werke $\mathrm{GmbH}$ (RWI), Germany. The detail engineering of this plant was done by Tata Consulting Engineers. The plant has been in operation for more than 30 Years and has today become a major source of Overhead Conductors, XLPE Cables \& Porcelain Insulators to worldwide companies. The present plant capacity has reached up to 14400 M.T. per month.

\section{LITERATURE REVIEW}

Chelte (1983) "Quality of Working Life of employees in organization is the quality of relationship among employees and total working environment, with human dimensions, technical and economic considerations".

Graver Robert F (1983) "Quality of Working Life is more than fad, more than any attempt to pacify growing demands of impatient employees and for the manager, Quality of Working Life can offer new challenges, opportunities for growth and satisfaction to employees in organization".

Warr, P, Cook, J \& Wall (1979), Danna, K., \& Griffin, R. W. (1999). Sirgy, Efraty, Siegel et al. (2001) "Quality of Working Life of Employees in Organization is considered as a range of apparently relevant Factors including Work Environment, Employees Involvement, Intrinsic Employees Motivation, Job Security, Higher Order Need Strength, Perceived Intrinsic Job Characteristics, Job Satisfaction, Life Satisfaction, Happiness \& Self Rated Anxiety".

Daya Narayan (1997) "In organizational design and development, Quality of Working Life of employees in organization is considered as an approach seeking to improve work environment and employee employer relationship".
Nadler, D.A \& E.E. Lawler III (1983), Robbins, S. P. (1998) "Quality of Working Life of employees in organization refer to those methods that attempt to serve both individual employee needs and organizational effectiveness by involving employees in decision making and problem solving activities".

Beukema, L. (1987), Groningen et al. "Quality of Working Life of employees in organization is defined as the degree to which employees are able to shape their jobs actively, in accordance with their options, opinions, interests and needs while employed in firm. It is the degree of power an organization imparts to their employees to design their lives at work place".

Robbins (1989) "Quality of Working Life of employees in organization is defined as a process by which an organization responds to employee needs by developing mechanisms to allow them to share fully in decision making that design their lives at work".

Keith (1989) "Quality of Working Life of employees in organization refers to favourableness or unfavourableness of a job environment of employees working in it".

Havlovic, S. J. (1991) Scobel, D. N et al. "Quality of Working Life of employees in organization include job security and satisfaction, better reward systems, incentives and compensation, higher pay, opportunity for career growth and participative groups among others".

\section{RESEARCH METHODOLOGY}

Area of study: Insulators \& Electricals Company, Mandideep.

Research Instrument: Structured Questionnaire \& Personal Interviews.

Sample Size: 100 employees of I.E.C

Sampling Technique: Convenient \& Random Sampling Technique

Research Type: Descriptive.

Data Collection: The Primary Data was collected through structured questionnaire that has been prepared to get relevant information from respondents through close ended multiple choice questions. Secondary Data was collected from Books, Journals, 
International Journal of Trend in Scientific Research and Development (IJTSRD) ISSN: 2456-6470

Monographs, Unpublished Thesis, Government Reports \& through Internet.

\section{Hypothesis}

$\mathrm{H}_{0}$ Quality of Working Life has no impact on employee's productivity

$\mathrm{H}_{1}$ Quality of Working Life has impact on employee's productivity

In this study, subjective productivity measurement method is used by researcher. The measures of this method are not defined on the basis of quantitative operational information but they are based on personnel's subjective assessments taken by researcher. Wang \& Gianakis (1999) have defined "subjective performance measure as an indicator used to assess individuals' aggregated perceptions, attitudes or assessments towards an organization product or service". Subjective productivity data is usually collected through survey questionnaires and personal interviews of respondents.

\section{DATA ANALYSIS \& INTERPRETATION}

By using Descriptive static technique frequencies distributions were made to determine Demographic Features of Respondents, Quality of Work / Life Variables \& Organization.

\section{Correlation between different variables of Quality of Working Life \& Productivity with respect to I.E.C}

\begin{tabular}{|l|c|}
\hline \multicolumn{1}{|c|}{$\begin{array}{c}\text { Variables of Quality of Work } \\
\text { Life }\end{array}$} & $\begin{array}{c}\text { Correlation } \\
\text { Values }\end{array}$ \\
\hline Creche Facility & 0.6451230212 \\
\hline Work Culture & 0.8837397365 \\
\hline Working Hours & 0.9340747958 \\
\hline Alternative Work Schedule & 0.7994628005 \\
\hline Leave Travel Concession & 0.6148153750 \\
\hline Pay Scale & 0.7765616805 \\
\hline Job Rotation \& Work Autonomy & 0.7091334775 \\
\hline $\begin{array}{l}\text { Social Integration \& } \\
\text { Constitutionalism at Workplace }\end{array}$ & 0.7560080980 \\
\hline Job Satisfaction & 0.8837202135 \\
\hline Safety Measures at Workplace & 0.5294126705 \\
\hline Transportation Facility & 0.4829819421 \\
\hline Accommodation Facility & 0.9672166267 \\
\hline Leave Facility & 0.7527721687 \\
\hline School Facility & 0.8413349559 \\
\hline Medical Facility & 0.7824470983 \\
\hline Vocational Training Facility & 0.6234775021 \\
\hline Training \& Development & 0.6794328488 \\
\hline
\end{tabular}

\begin{tabular}{|l|l|}
\hline $\begin{array}{l}\text { Stress Management \& } \\
\text { Recreational Facility }\end{array}$ & 0.5877117612 \\
\hline Career Growth Opportunities & 0.3362542201 \\
\hline Grievance Redressal System & 0.9291313060 \\
\hline $\begin{array}{l}\text { Employees Involvement in } \\
\text { Management }\end{array}$ & 0.2238099690 \\
\hline Work -Life Balance & 0.6593021206 \\
\hline $\begin{array}{l}\text { Canteen \& Drinking Water } \\
\text { Facility }\end{array}$ & 0.7055346156 \\
\hline Promotion Policy & 0.9129621293 \\
\hline Corporate Social Responsibility & 0.6773020724 \\
\hline Rewards \& Recognition & 0.8879411260 \\
\hline $\begin{array}{l}\text { Bonus, Incentives \& } \\
\text { Compensation }\end{array}$ & 0.8264234180 \\
\hline
\end{tabular}

Thus, researcher has used correlation technique to determine impact of Quality of Working Life of Employees on their Productivity of Insulators \& Electricals Company, Mandideep. The researcher has found positive correlation of each Quality of Working Life Variables regarding Employees Productivity that itself represents that Quality of Working Life of Employees in I.E.C has deep impact on their Productivity.

\section{CONCLUSION}

Work is the most essential part of every individual's life as it is livelihood and career of a human being. Organizations are made up of individuals and can only function with the help of individuals. Without individuals any organization cannot exist or run smoothly. The various sources of production such as Men, Money, Materials \& Machinery are collected together, coordinated and utilized through human beings in an organization. Other factors of production cannot work without involvement of human resource in any organization. Human capital is real asset for any organization and can become secret for organizational success and all other sources of production can only be utilized and managed through human resources only. So, it is extremely essential to gain involvement of these human assets in every work area in order to ensure efficiency, performance and productivity. Thus, Insulators \& Electricals Company is pioneer in maintaining Quality of Working Life of Employees within organization that is proving to be a milestone in industrial sector which not only enhances their employee's productivity and skills but also leads to profit and wealth maximization of I.E.C. 


\section{REFERENCES}

1. Arthur, M.B., Hall, D.T., \& Lawrence, B.S. (Eds.) (1989) - Handbook of Career Theory, Cambridge: Cambridge University Press.

2. Baba, VV \& Jamal, M (1991) - Routinisation of Job Context \& Job Content as related to Employees Quality of Working Life: a study of psychiatric nurses. Journal of Oganizational Behaviour, volume 12, page 379 - 386.

3. Bear field, S (2003) - Quality of Working Life. Aciirt Working paper 86, University of Sydney www.acirrt.com.

4. Berry, L. M. (1998) - Psychology at Work: An introduction to Industrial \& Organizational Psychology, San Francisco: McGraw - Hill.

5. Cannings, K. \& Montmarquette, C (1991) Managerial Momentum: a Simultaneous Model of the Career Progress of Male \& Female Managers, Industrial \& Labour Relations, Review volume 44, page $212-228$.

6. Cascio, W.F. (2003) - Managing Human Resources: Productivity, Quality of Work Life, Profits. (6th edition), New York: McGraw - Hill.

7. Cox, C.J. \& Cooper, C.L. (1989) - The making of the British Chief Executive Officer: Childhood, Work Experience, Personality \& Management Style. Academy of Management Executive, volume 3, page $241-245$.

8. Cunningham, J.B. \& T. Eberle (1990) - A guide to Job Enrichment \& Redesign. Personnel, volume 67 , page $56-61$.

9. Danna, K. \& Griffin, R. W. (1999) - Health \& Well - Being in the Workplace: A review \& synthesis of the literature, Journal of Management, volume 25 , page $357-384$.

10. Edwards, J., Van Laar, D.L. \& Easton, S. (2009) The Work - Related Quality of Life scale for Higher Education Employees, Quality in Higher Education, Volume 15: 3, page 207 - 219.

11. Ellis N \& Pompli A (2002) - Quality of Working Life for nurses. Common Wealth Department of Health \& Ageing, Canberra.

12. Feuer, D. (1989) - Quality of Work Life: a cure for all ills? Training: The magazine of Human Resources Development, volume 26, page 65 66.
13. Greenhaus, J.H., Parasuraman, S \& Wormley, W.M. (1990) - Effects of Race on Organizational Experience, Job Performance Evaluations \& Career Outcomes. Academy of Management Journal, volume 16, page $129-137$.

14. Hackman J \& Oldham G (1974) - The Job Diagnostic Survey, New Haven: Yale University.

15. Lawler, E. E. (1982) - Strategies for improving the Quality of Work Life, American Psychologist volume 37, year 2005, page 486 - 493.

16. Lewis, S. \& C.L. Cooper (1999) - The Work Family research agenda in changing contexts, Journal of Occupational Health Psychology, volume 4 , page $382-393$.

17. Loscocco, K. A. \& Roschelle, A. N. (1991) Influences on the Quality of Work \& Nonwork Life: Two Decades in Review, Journal of Vocational Behaviour, volume 39, page 182 225.

18. Shamir, B. \& I. Salomon (1985) - Work - At Home \& the Quality of Working Life, Academic Management, volume 10, page 455 - 464.

19. Sirgy, M. J., Efraty, D., Siegel, P \& Lee, D. (2001) - A new measure of Quality of Work Life based on Need Satisfaction \& Spillover Theories. Social Indicators Research, volume 55, page 241 302.

20. Straw, R.J. \& C.C. Heckscher (1984) - Quality of Work Life: New Working Relationships in the Communication Industry, Labour Studies Journal, volume 9, page $261-274$.

21. Taylor J C in Cooper, CL \& Mumford, E (1979) The Quality of Working Life in Western \& Eastern Europe. ABP.

22. Walton, R.E. (1975) - Criteria for Quality of Working Life. In Davis, L. E., Cherns, A.B. Associates (Eds.) The Quality of Working Life, The Free Press, New York, NY, volume 1, page $91-104$.

23. Warr, P, Cook, J \& Wall, T (1979) - Scales for the measurement of some Work Attitudes Aspects of Psychological Well Being. Journal of Occupational Psychology 52, page $129-148$

24. WWW.QWL.COM

25. WWW.IEC.COM 